\title{
PHYSIOLOGICAL STUDIES ON GERMINATION AND FERTILIZATION OF SOPHORA PLANT \\ 2.EFFECT OF SOME FERTILIZATION TREATMENTS ON GROWTH AND CHEMICAL COMPOSITION Of Sophora secundiflora SEEDLINGS
}

(Received: 23.12.2020)

\author{
By \\ A. W. Sayed \\ Ornamental Plants and Landscape Gardening Research Department, Horticulture Research \\ Institute, Agriculture Research Center, Giza, Egypt
}

\begin{abstract}
An investigation was conducted at the nursery of Al-Zohriya Garden, Hort. Res. Inst., ARC, Giza, Egypt during 2018 and 2019 seasons to evaluate the positive effects of both Kristalon ( $20 \mathrm{~N}$ : 20 P: $20 \mathrm{~K}+$ microelements) and Active Grow a commercial liquid nutritive product that contains macro and micro-elements, $\mathrm{GA}_{3}$, amino acids, vit. $\mathrm{B}$. and molas) when applied at $0,1,2,3$ and $4 \mathrm{~g} / \mathrm{ml}$, or $\mathrm{ml}$ for Kristalon $/ 1$ for Active Grow as foliar spray, biweekly on growth and quality of Mescal-bean (Sophora secundiflora (Ort.) Lag ex.DC.) during the growth period in the nursery. The obtained results showed that spraying plants with all fertilization treatments traits exhibited significant increasing in the average of vegetative and root growth compared to the control treatment where the treatments was of the integrated mineral fertilizer Kristalon (20:20:20) at the rate of $3 \mathrm{~g} / \mathrm{l}$, the best treatment,which gave the highest values in all traits, in both seasons. On the other hand the lowest values were found in the untreated plants (control), followed by the plants treated with the high rate of Active Grow $(4 \mathrm{ml} / \mathrm{l})$ treatment . The same trend was observed with regard to the chemical components of the leaves, with the Kristalon treatment at the rate of $3 \mathrm{~g} / \mathrm{l}$, which gave the highest values for the leaf contents of photosynthetic pigments (chlorophyll- $a, b$ and carotenoids), total soluble sugars, nitrogen, phosphorus, potassium, as well as iron, manganese, magnesium and zinc compared to other treatments for the mean of the two seasons. Accordingly, foliar spraying of Mescalbean (Sophora secundiflora) seedlings with Kristalon compound (20 N: 20 P: $20 \mathrm{~K}+$ microelements) at the rate of $3 \mathrm{~g} /$ liter, once every two weeks during the growing season, can be recommended to obtain the fastest growth and high quality during the period of nursery care.
\end{abstract}

Key words: Mescal-bean, Sophora secundiflora, vegetative and root growth, Kristalon, Active Grow, chlorophylls, carotenoids, total soluble sugars.

\section{INTRODUCTION}

Sophora secundiflora ((Ort.) Lag ex. DC.), Mescal-bean or Texas mountain laurel is a small tree with evergreen compound leaves, that belongs to the pea family (Fabaceae). It is native to dry, rocky limestone soils from central Texas west to New Mexico and is drought-resistant after establishment. It bears beautiful lavenderamethyst colored clusters of pea-like, aromatic flowers. So, it makes a beautiful specimen plant either in the landscape or in containers. The beans contain the alkaloid sophorine, which is identical with cytosine (Huxley et al., 1992).

Mescal-bean is a slow- growth shrub, it may needs years before blooming. Thus, young plants require some extra nutrition to get quickly established. Information in the literature regarding Sophora nutrition are very limited. But, there are several studies on the other ornamental shrubs. In this concern, Shahin et al. (2012) found that dressing Brassaia actinophylla and Euonymus japonicus cv." Aureus" plants with $2 \mathrm{~g} /$ pot Kristalon $+5 \mathrm{~g} / \mathrm{l}$ active dry yeast as foliar spray greatly improved vegetative and root growth of both plants, with increasing pigments, $\mathrm{N}, \mathrm{P}$ and $\mathrm{K}$ concentrations in their leaves. Likewise, El-Fouly et al.(2014) reported that spraying the foliage of Cordyline terminalis monthly with humic acid + liquid fertilizer (10 $\mathrm{N}$ : $10 \mathrm{P}: 10 \mathrm{~K}+$ microelements) and Citreen (a commercial nutritive and growth activator liquid product contains $\mathrm{Fe}, \mathrm{Zn}, \mathrm{Mn}$, and organic acids) 
at $5 \mathrm{ml} / \mathrm{l}$ for each markedly improved all vegetative and root growth characters and leaf properties of the mixture used in both seasons are shown in Table (a).

Table (a): Some physical and chemical properties of the soil mixture used in this study.

\begin{tabular}{|c|c|c|c|c|c|c|c|c|c|c|c|}
\hline \multirow{2}{*}{ Soil mixture } & \multicolumn{4}{|c|}{ Particle size distribution (\%): } & \multirow{2}{*}{ S.P. } & \multirow{2}{*}{$\begin{array}{c}\text { E.C. } \\
\text { (dS/m) }\end{array}$} & \multirow{2}{*}{ pH } & \multicolumn{4}{|c|}{ Cations (meq/l) } \\
\hline & & & Silt & Clay & & & & $\mathrm{Ca}^{++}$ & $\mathrm{Mg}^{++}$ & $\mathrm{Na}^{+}$ & $\mathbf{K}^{+}$ \\
\hline \multirow{4}{*}{$\begin{array}{c}\text { Sand + clay } \\
\text { mixture } \\
(1: 1, v / v)\end{array}$} & & & 37.5 & 23.5 & 27.0 & 3.4 & 7.58 & 13.5 & 10.5 & 18.8 & 0.65 \\
\hline & \multicolumn{4}{|c|}{ Anions (meq/l) } & \multicolumn{7}{|c|}{ Macro and micro-elements (ppm) } \\
\hline & $\mathrm{HCO}_{3}^{-}$ & $\mathrm{Cl}^{-}$ & $\mathrm{SO}_{4}^{--}$ & $\mathrm{CO}_{3}^{--}$ & $\mathbf{N}$ & $\mathbf{P}$ & $\mathbf{K}$ & $\mathbf{F e}$ & $\mathbf{Z n}$ & Mn & $\mathbf{C u}$ \\
\hline & 1.5 & 28.5 & 13.45 & - & 5.00 & 19.00 & 2.60 & 4.10 & 0.58 & 2.10 & 0.16 \\
\hline
\end{tabular}

contents of chlorophylls a, b, carotenoids, anthocyanin, carbohydrates, Fe, $\mathrm{Zn}$ and $\mathrm{Mn}$.

Several reports, by El-Mokadem and Sorour (2014) on Petunia hybrida cv. "Bravo White", Ibrahim et al.(2014) on Tulbaghia violacea, Abou-Dahab et al.(2015) on Kochia scoparia, Arab et al. (2015) on Calendula officinalis, ElFouly (2015) on Ochna serrulata, Naseem et al. (2015) on Murraya exotica, Fayaz et al., (2016) on gerbera, Ali et al., (2017) on Moringa oleifera, Badran et al.(2017) on gardenia, Abdou and Badran (2018) on Delonix regia, El-Azzony et al. (2018) on Jatropha curcas, Shahin and Dorgham (2018) on Browallia speciosa and Thevetia peruviana, Arafa et al. (2019) on Ixora coccinea agree with Said and Shahin (2019), who mentioned that spraying the foliage of Eucalyptus citriodora seedlings with the aqueous solution of amino acids mixture at $1 \mathrm{~g} / \mathrm{l}$ maximized the means of plant height, stem diameter, No. leaves/plant, root length, fresh and dry weights of different plant organs, as well as leaf content of pigments, total soluble sugars, $\mathrm{P}$ and $\mathrm{K}$.

This trail was set out in order to investigate the response of the slow-growing Mescal-bean seedlings to some fertilization treatments, e.g. foliar nutrition of Kristalon and Active Grow during the growth period in the nursery.

\section{MATERIALS AND METHODS}

The current work was carried out at the nursery of Al-Zohriya Garden, Hort. Res. Inst., ARC, Giza, Egypt during 2018 and 2019 seasons aiming to determine the positive effects of two commercial fertilizers on growth and chemical composition of Mescal-bean seedlings.

Therefore, uniform 6-month-old seedlings of Sophora secundiflora ((Ort.) Lag ex. DC.) at a length of about $10 \mathrm{~cm}$ with 8 leaves were individually transplanted on March, $15^{\text {th }}$ (both seasons) into $16 \mathrm{~cm}$ diameter plastic pots, each filled with about $1.5 \mathrm{~kg}$ of sand and clay mixture $(1: 1, \mathrm{v} / \mathrm{v})$. Some physical and chemical
After two weeks (on April, $1^{\text {st }}$ in every season), the seedlings received the following fertilization treatments.

1. Non fertilization, referred to as control.

2. The aqueous solution of either Kristalon fertilizer $(20 \mathrm{~N}$ : $20 \mathrm{P}: 20 \mathrm{~K}+$ microelements, produced by Agrico International Company, Dokki , Giza) at the rates of 1, 2, 3 and $4 \mathrm{~g} / \mathrm{l}$.

3- Active Grow (a liquid commercial nutritive product produced by Agro Egypt International, Al-Sadat city) at the rates of $1,2,3$ and $4 \mathrm{ml} / \mathrm{l}$. The chemical components of this product are listed in Table (b).

Table (b): The chemical components of the Active Grow commercial product used in the two seasons (2018 and 2019).

\begin{tabular}{|l|l|l|l|}
\hline $\mathbf{N}$ & $8.00 \%$ & $\mathbf{B}$ & $0.02 \%$ \\
\hline $\mathbf{P}$ & $5.00 \%$ & $\mathbf{S}$ & $2.10 \%$ \\
\hline $\mathbf{K}$ & $6.00 \%$ & $\mathbf{G A}_{3}$ & $0.001 \%$ \\
\hline $\mathbf{F e}$ & $3000 \mathrm{ppm}$ & free amino acids & $10.18 \%$ \\
\hline $\mathbf{M n}$ & $3000 \mathrm{ppm}$ & $\mathbf{C P U}$ & $0.001 \%$ \\
\hline $\mathbf{Z n}$ & $3000 \mathrm{ppm}$ & Minatole & $3.00 \%$ \\
\hline $\mathbf{M g}$ & $5000 \mathrm{ppm}$ & Vitamin B complex & $0.01 \%$ \\
\hline Genk & $15.00 \%$ & Molas & $5.00 \%$ \\
\hline
\end{tabular}

The aqueous solution of the abovementioned products were sprayed on the seedling foliage at early morning till run-off point, every two weeks. The layout of the experiment was a completely randomized design, replicated thrice, and each replicate contained four plants (Mead et al., 1993). All plants received the necessary agricultural practices whenever needed.

At the end of each season (on October, $15^{\text {th }}$ ), the data were recorded on the following traits: plant height $(\mathrm{cm})$, number of leaflets/plant, stem diameter $(\mathrm{mm})$, leaflet area $\left(\mathrm{cm}^{2}\right)$, root length $(\mathrm{cm})$, as well as top growth and roots fresh and dry weights (g/plant ).

In the fresh leaf samples was taken from the middle parts of plants, the content of 
photosynthetic pigments (chlorophyll a, b and carotenoids mg/g f. w.) Sumanta et al. (2014) the percent of total soluble sugars was determined according to the methods of Dubois et al. (1956). At the end of the two seasons, the percentages of nitrogen (Blacke, 1965), phosphorus (Luatanab and Olsen, 1965) as well as potassium (Jackson, 1973) were determine in the dry leaves. In the mean of both seasons, another dry leaf samples were digested in nitric and perchloric acids and analyzed to determine the contents of iron, manganese, magnesium, and zinc (as ppm) using Perkin Elmer 403 atomic absorption spectrophotometer as indicated by Jackson (1973).

Data obtained were then tabulated and statistically analyzed using computer program of SAS Institute (2009), which was followed by Duncan's New Multiple Range t-Test (Steel and Torrie, 1980) to compare means of treatments .

\section{RESULTS AND DISCUSSION}

\subsection{Effect of fertilization treatments}

\subsubsection{Vegetative and root growth characteristics}

It is evident from the data presented in Tables (1, 2 and 3) the most fertilization treatments applied in this study significantly increased the means of plant height $(\mathrm{cm})$, number of leaflets/plant, stem diameter $(\mathrm{mm})$, leaflet area $\left(\mathrm{cm}^{2}\right)$, root length $(\mathrm{cm})$ as well as fresh and dry weights of top growth and roots as compared to control treatment with the superiority of Kristalon treatment (20 N: 20 P: $20 \mathrm{~K}$ ) at $3 \mathrm{~g} / 1$ that gave the highest scores compared to other treatments in both seasons.
On the other hand, increasing the Kristalon rate to $4 \mathrm{~g} / 1$ did not caused any further improvement in the mean values of growth characteristics, which were lower than those achieved at the 3 g/l level.

Likewise, the Active Grow at $4 \mathrm{ml} / \mathrm{l}$ treatment had the lowest growth values compared to the $2 \mathrm{ml} / \mathrm{l}$ treatment in both seasons (Figs.1and 2).

Stimulation of plant growth by fertilization may be reasonable because different nutrients of fertilizers usually activate metabolism in plant cells, producing sugars, proteins, hormones, enzymes and energy-reverse materials necessary for good and healthy growth. This truth was documented by Ibrahim et al. (2014) who declared that fertilizing Tulbaghia violacea (flowering-pot-plant) with NPK mixture at 1 $\mathrm{g} /$ pot + foliar spray with humic acid at $2 \mathrm{ml} / \mathrm{l}$ greatly improved growth, flowering and leaf content of pigments, sugars, $\mathrm{N}, \mathrm{P}$ and $\mathrm{K}$; likewise, Fayaz et al.(2016) suggested that treatment composed of 20:20:15 NPK at $\mathrm{g} / \mathrm{m}^{2}$ could be useful for the best vegetative and reproductive characters of gerbera cv. Lanceolat. On Delonix regia, Abdou and Badran (2018) revealed that supplying with either medium or high NPK rate $+\mathrm{Mn}$ and $\mathrm{Zn}$ each at $75 \mathrm{ppm}$, resulted the best growth of seedlings grown in sandy soil. On the same results were achieved by Abou Dahab et al.(2015) on Kochia scoparia, Ali et al. (2017) on moringa, Badran et al. (2017) on Gardenia jasminoides, El-Azzony et al. (2018) on Jatropha curcas and Arafa et al. (2019) on Ixora cocconea.

Table (1): Effect of fertilization treatments on plant height, number of leaflets /plant and stem diameter of Sophora secundifora plants during 2018 and 2019 seasons.

\begin{tabular}{|l|c|c|c|c|c|c|}
\hline \multirow{2}{*}{\multicolumn{1}{|c|}{ Treatments }} & \multicolumn{2}{c|}{$\begin{array}{c}\text { Plant height } \\
\text { (cm) }\end{array}$} & \multicolumn{2}{c|}{ No. leaflets /plant } & \multicolumn{2}{c|}{$\begin{array}{c}\text { Stem diameter } \\
\text { (mm) }\end{array}$} \\
\cline { 2 - 7 } & $\mathbf{2 0 1 8}$ & $\mathbf{2 0 1 9}$ & $\mathbf{2 0 1 8}$ & $\mathbf{2 0 1 9}$ & $\mathbf{2 0 1 8}$ & $\mathbf{2 0 1 9}$ \\
\hline Control & $13.90 \mathrm{H}$ & $14.17 \mathrm{I}$ & $13.33 \mathrm{I}$ & $14.33 \mathrm{I}$ & $2.89 \mathrm{H}$ & $3.07 \mathrm{G}$ \\
\hline Kristalon 1 g/l & $19.77 \mathrm{D}$ & $20.70 \mathrm{D}$ & $26.33 \mathrm{D}$ & $29.33 \mathrm{D}$ & $4.38 \mathrm{D}$ & $4.75 \mathrm{D}$ \\
\hline Kristalon 2 g/l & $23.17 \mathrm{~B}$ & $23.67 \mathrm{~B}$ & $33.67 \mathrm{~B}$ & $36.33 \mathrm{~B}$ & $5.30 \mathrm{~B}$ & $5.48 \mathrm{~B}$ \\
\hline Kristalon 3 g/l & $25.27 \mathrm{~A}$ & $32.13 \mathrm{~A}$ & $44.00 \mathrm{~A}$ & $52.67 \mathrm{~A}$ & $5.90 \mathrm{~A}$ & $6.70 \mathrm{~A}$ \\
\hline Kristalon 4 g/l & $18.57 \mathrm{E}$ & $18.90 \mathrm{E}$ & $22.83 \mathrm{E}$ & $24.00 \mathrm{E}$ & $4.15 \mathrm{E}$ & $4.26 \mathrm{E}$ \\
\hline Active Grow 1 ml/l & $16.87 \mathrm{~F}$ & $17.30 \mathrm{G}$ & $18.33 \mathrm{G}$ & $20.00 \mathrm{G}$ & $3.84 \mathrm{~F}$ & $4.02 \mathrm{EF}$ \\
\hline Active Grow 2 mI/l & $20.70 \mathrm{C}$ & $22.40 \mathrm{C}$ & $27.67 \mathrm{C}$ & $31.33 \mathrm{C}$ & $4.86 \mathrm{C}$ & $5.03 \mathrm{C}$ \\
\hline Active Grow 3 mI/l & $17.20 \mathrm{~F}$ & $18.13 \mathrm{~F}$ & $20.33 \mathrm{~F}$ & $21.72 \mathrm{~F}$ & $3.91 \mathrm{~F}$ & $4.08 \mathrm{EF}$ \\
\hline Active Grow 4 mI/l & $15.40 \mathrm{G}$ & $16.17 \mathrm{H}$ & $15.33 \mathrm{H}$ & $16.33 \mathrm{H}$ & $3.49 \mathrm{G}$ & $3.86 \mathrm{~F}$ \\
\hline
\end{tabular}

*Means within a column having the same letters are not significantly different according to Duncan's New Multiple Range t-Test at $5 \%$ level. 
Table (2) : Effect of fertilization treatments on leaflet area and root length of Sophora secundifora plants during 2018 and 2019 seasons.

\begin{tabular}{|l|c|c|c|c|}
\hline \multirow{2}{*}{ Treatments } & \multicolumn{2}{c|}{$\begin{array}{c}\text { Leaflet area } \\
\left(\mathbf{c m}^{\mathbf{2}}\right)\end{array}$} & \multicolumn{2}{c|}{$\begin{array}{c}\text { Root length } \\
\text { (cm) }\end{array}$} \\
\cline { 2 - 5 } & $\mathbf{2 0 1 8}$ & $\mathbf{2 0 1 9}$ & $\mathbf{2 0 1 8}$ & $\mathbf{2 0 1 9}$ \\
\hline Control & $1.60 \mathrm{H}$ & $1.74 \mathrm{H}$ & $10.43 \mathrm{I}$ & $14.93 \mathrm{I}$ \\
\hline Kristalon $\mathbf{1 ~ g / l ~}$ & $3.36 \mathrm{D}$ & $3.90 \mathrm{D}$ & $21.70 \mathrm{D}$ & $22.50 \mathrm{D}$ \\
\hline Kristalon $\mathbf{2 ~ g / l ~}$ & $5.38 \mathrm{~B}$ & $5.94 \mathrm{~B}$ & $25.77 \mathrm{~B}$ & $27.77 \mathrm{~B}$ \\
\hline Kristalon 3 g/l & $5.83 \mathrm{~A}$ & $7.28 \mathrm{~A}$ & $30.97 \mathrm{~A}$ & $36.23 \mathrm{~A}$ \\
\hline Kristalon 4 g/l & $2.96 \mathrm{E}$ & $3.11 \mathrm{E}$ & $20.83 \mathrm{E}$ & $21.13 \mathrm{E}$ \\
\hline Active Grow 1 ml/l & $2.25 \mathrm{G}$ & $2.65 \mathrm{~F}$ & $18.50 \mathrm{G}$ & $19.33 \mathrm{G}$ \\
\hline Active Grow 2 ml/l & $4.20 \mathrm{C}$ & $4.70 \mathrm{C}$ & $22.80 \mathrm{C}$ & $23.97 \mathrm{C}$ \\
\hline Active Grow 3 ml/l & $2.59 \mathrm{~F}$ & $2.82 \mathrm{EF}$ & $19.57 \mathrm{~F}$ & $20.17 \mathrm{~F}$ \\
\hline Active Grow 4 ml/l & $1.84 \mathrm{H}$ & $2.19 \mathrm{G}$ & $15.87 \mathrm{H}$ & $17.67 \mathrm{H}$ \\
\hline
\end{tabular}

*Means within a column having the same letters are not significantly different according to Duncan's New Multiple Range t-Test at $5 \%$ level.

Table (3): Effect of fertilization treatments on top growth and roots fresh and dry weights of Sophora secundifora plants during 2018 and 2019 seasons.

\begin{tabular}{|c|c|c|c|c|c|c|c|c|}
\hline \multirow{3}{*}{ Treatments } & \multicolumn{4}{|c|}{ Top growth/plant } & \multicolumn{4}{|c|}{ Roots\plant } \\
\hline & \multicolumn{2}{|c|}{$\begin{array}{c}\text { Fresh weight } \\
\text { (g) }\end{array}$} & \multicolumn{2}{|c|}{$\begin{array}{c}\text { Dry weight } \\
\text { (g) }\end{array}$} & \multicolumn{2}{|c|}{$\begin{array}{c}\text { Fresh weight } \\
\text { (g) }\end{array}$} & \multicolumn{2}{|c|}{$\begin{array}{c}\text { Dry weight } \\
\text { (g) }\end{array}$} \\
\hline & 2018 & 2019 & 2018 & 2019 & 2018 & 2019 & 2018 & 2019 \\
\hline Control & $1.98 \mathrm{I}$ & $2.93 \mathrm{H}$ & $0.84 \mathrm{G}$ & $1.30 \mathrm{G}$ & $0.91 \mathrm{I}$ & $1.03 \mathrm{H}$ & $0.26 \mathrm{I}$ & $0.40 \mathrm{G}$ \\
\hline Kristalon 1 g/l & $6.86 \mathrm{D}$ & $7.20 \mathrm{C}$ & $2.78 \mathrm{CD}$ & $3.11 \mathrm{C}$ & $2.41 \mathrm{D}$ & $2.56 \mathrm{D}$ & $0.95 \mathrm{D}$ & $1.11 \mathrm{D}$ \\
\hline Kristalon 2 g/l & $8.51 \mathrm{~B}$ & $9.85 \mathrm{~B}$ & $3.65 \mathrm{~B}$ & $4.12 \mathrm{~B}$ & $3.52 \mathrm{~B}$ & $3.82 \mathrm{~B}$ & $1.34 \mathrm{~B}$ & $1.79 \mathrm{~B}$ \\
\hline Kristalon 3 g/l & $11.42 \mathrm{~A}$ & $16.32 \mathrm{~A}$ & $4.73 \mathrm{~A}$ & $7.53 \mathrm{~A}$ & $4.27 \mathrm{~A}$ & $6.00 \mathrm{~A}$ & $1.87 \mathrm{~A}$ & $3.43 \mathrm{~A}$ \\
\hline Kristalon 4 g/l & $6.01 \mathrm{E}$ & $6.28 \mathrm{D}$ & $2.52 \mathrm{D}$ & $2.63 \mathrm{D}$ & $2.06 \mathrm{E}$ & $2.22 \mathrm{E}$ & $0.82 \mathrm{E}$ & $1.03 \mathrm{D}$ \\
\hline Active Grow 1ml/l & $4.23 \mathrm{G}$ & $4.67 \mathrm{~F}$ & $1.88 \mathrm{EF}$ & $2.00 \mathrm{EF}$ & $1.49 \mathrm{G}$ & $1.62 \mathrm{G}$ & $0.52 \mathrm{G}$ & $0.64 \mathrm{~F}$ \\
\hline Active Grow 2 ml/l & $7.37 \mathrm{C}$ & $7.66 \mathrm{C}$ & $3.05 \mathrm{C}$ & $3.25 \mathrm{C}$ & $2.79 \mathrm{C}$ & $3.09 \mathrm{C}$ & $1.18 \mathrm{C}$ & $1.46 \mathrm{C}$ \\
\hline Active Grow 3 ml/l & $5.00 \mathrm{~F}$ & $5.34 \mathrm{E}$ & $2.10 \mathrm{E}$ & $2.28 \mathrm{DE}$ & $1.74 \mathrm{~F}$ & $1.93 \mathrm{~F}$ & $0.64 \mathrm{~F}$ & $0.82 \mathrm{E}$ \\
\hline Active Grow 4 ml/l & $3.65 \mathrm{H}$ & $4.07 \mathrm{G}$ & $1.59 \mathrm{~F}$ & $1.77 \mathrm{~F}$ & $1.14 \mathrm{H}$ & $1.42 \mathrm{G}$ & $0.40 \mathrm{H}$ & $0.49 \mathrm{FG}$ \\
\hline
\end{tabular}

* Means within a column having the same letters are not significantly different according to Duncan's New Multiple Range t-Test at $5 \%$ level.

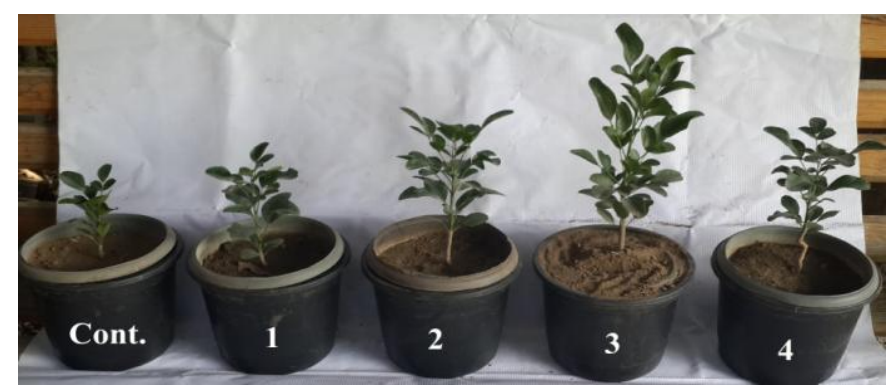

Fig. (1): Effect of Kristalon treatments on Sophora secundifora seedlings growth. Treatments from left to right: control. 1: Kristalon at $1 \mathrm{~g} / \mathrm{l} \mathrm{.2:} \mathrm{Kristalon} \mathrm{at} 2 \mathrm{~g} / \mathrm{l} .3$ : Kristalon at $3 \mathrm{~g} / \mathrm{l}$ and4:Kristalon at $4 \mathrm{~g} / \mathrm{l}$.

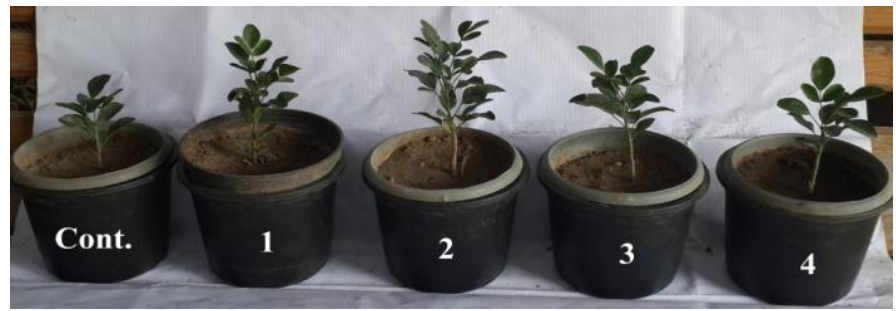

Fig. (2): Effect of Active Grow treatments on Sophora secundifora seedlings growth. Treatments from left to right: control.1: Active Grow at 1ml/l. 2: Active Grow at $2 \mathrm{ml} / \mathrm{l}$. 3: Active Grow at 3mlg/l and 4: Active Grow at $4 \mathrm{ml} / \mathrm{l}$. 


\subsubsection{Chemical composition of the leaves}

The data in Tables (4, 5 and Fig. 3) showed that all Kristalon doses caused a significant increase in photosynthetic pigments content (chlorophyll a, b and carotenoids, $\mathrm{mg} / \mathrm{g}$ f. w.), as well as the percentages of total soluble sugars, $\mathrm{N}, \mathrm{P}$, and $\mathrm{K}$ contents in the leaf tissue of treated with plants as compared with untreated plants (the control). The highest values in this regard were recorded by Kristalon-treated plants at 3 $\mathrm{g} / \mathrm{l}$. While, the lowest contents were found in the leaves of Kristalon-treated plants at $4 \mathrm{~g} / \mathrm{l}$. A similar response was also occurred regarding the concentrations of $\mathrm{Fe}, \mathrm{Mn}, \mathrm{Zn}$ and $\mathrm{Mg}$.

Similarly, the Active Grow at $4 \mathrm{ml} / \mathrm{l}$ treatment had the lowest leaf chemical composition values compared to the $2 \mathrm{ml} / \mathrm{l}$ treatment in the mean of both seasons.

Generally, improving concentration of active constituents in plant tissues due to nutritive treatments is sensible because such treatments usually supply the plants with more available nutrients, which accelerate biosynthesis processes and lead finally to accumulate more active components in plant cells. In this respect, El-Fouly (2015) mentioned that spraying the foliage of Ochna serrulata seedlings with Vege Grow liquid fertilizer at 2 $\mathrm{ml} / \mathrm{l}$ maximized leaf content of chlorophyll $\mathrm{a}, \mathrm{b}$, carotenoids, total soluble sugars, $\mathrm{N}, \mathrm{P}, \mathrm{K}, \mathrm{Fe}, \mathrm{Zn}$, $\mathrm{Cu}, \mathrm{Mn}$ and proteins. El-Azzony et al. (2018) pointed out that interacting between $75 \%$ NPK from the recommended dose and EM1 at 100 $\mathrm{ml} / \mathrm{shrub}$ of Jatropha increased fixed oil \%, fixed oil weight/shrub, fixed oil yield/fed. and improved percentages of palmitic, oleic, stearic and linoleic acids in the resulted fixed oil.

Table (4): Effect of fertilization treatments on pigments of Sophora secundifora plants during 2018 and 2019 seasons.

\begin{tabular}{|c|c|c|c|c|c|c|}
\hline \multirow[t]{2}{*}{ Treatments } & \multicolumn{2}{|c|}{$\begin{array}{c}\text { Chlorophyll a } \\
\text { mg/gm f.w }\end{array}$} & \multicolumn{2}{|c|}{$\begin{array}{c}\text { Chlorophyll b } \\
\text { mg/gm f.w }\end{array}$} & \multicolumn{2}{|c|}{$\begin{array}{c}\text { Carotenoids } \\
\text { mg/gm f.w }\end{array}$} \\
\hline & 2018 & 2019 & 2018 & 2019 & 2018 & 2019 \\
\hline Control & $0.443 \mathrm{E}$ & $0.446 \mathrm{H}$ & $0.068 \mathrm{E}$ & $0.134 \mathrm{~F}$ & $0.159 \mathrm{~F}$ & $0.176 \mathrm{~F}$ \\
\hline Kristalon 1 g/l & $0.612 \mathrm{~B}$ & $0.654 \mathrm{D}$ & $0.186 \mathrm{C}$ & $0.214 \mathrm{~B}$ & $0.259 \mathrm{~B}$ & $0.260 \mathrm{BC}$ \\
\hline Kristalon 2 g/l & $0.616 \mathrm{~B}$ & $0.721 \mathrm{~B}$ & $0.219 \mathrm{~B}$ & $0.234 \mathrm{~B}$ & $0.271 \mathrm{~B}$ & $0.300 \mathrm{~A}$ \\
\hline Kristalon $3 \mathrm{~g} / \mathrm{l}$ & $0.641 \mathrm{~A}$ & $0.762 \mathrm{~A}$ & $0.256 \mathrm{~A}$ & $0.368 \mathrm{~A}$ & $0.383 \mathrm{~A}$ & $0.307 \mathrm{~A}$ \\
\hline Kristalon $4 \mathrm{~g} / \mathrm{l}$ & $0.595 \mathrm{~B}$ & $0.608 \mathrm{E}$ & $0.185 \mathrm{C}$ & $0.209 \mathrm{BC}$ & $0.237 \mathrm{C}$ & $0.241 \mathrm{CD}$ \\
\hline Active Grow 1ml/l & $0.470 \mathrm{D}$ & $0.484 \mathrm{G}$ & $0.138 \mathrm{D}$ & $0.175 \mathrm{DE}$ & $0.207 \mathrm{D}$ & $0.217 \mathrm{DE}$ \\
\hline Active Grow 2 ml/l & $0.614 \mathrm{~B}$ & $0.672 \mathrm{C}$ & $0.192 \mathrm{BC}$ & $0.221 \mathrm{~B}$ & $0.265 \mathrm{~B}$ & $0.267 \mathrm{~B}$ \\
\hline Active Grow 3 ml/l & $0.529 \mathrm{C}$ & $0.562 \mathrm{~F}$ & $0.154 \mathrm{D}$ & $0.184 \mathrm{CD}$ & $0.225 \mathrm{C}$ & $0.227 \mathrm{DE}$ \\
\hline Active Grow 4 ml/l & $0.450 \mathrm{DE}$ & $0.459 \mathrm{H}$ & $0.136 \mathrm{D}$ & $0.149 \mathrm{EF}$ & $0.182 \mathrm{E}$ & $0.205 \mathrm{E}$ \\
\hline
\end{tabular}

*Means within a column having the same letters are not significantly different according to Duncan's New Multiple Range t-Test at $5 \%$ level.

Table (5): Effect of fertilization treatments on total soluble sugars, N, P, K and Mg concentrations in the leaves of Sophora secundifora plants (average of the two seasons).

\begin{tabular}{|l|c|c|c|c|c|}
\hline \multicolumn{1}{|c|}{ Treatments } & $\begin{array}{c}\text { Total soluble } \\
\text { sugars \% } \\
\text { (f. w.) }\end{array}$ & $\begin{array}{c}\mathbf{N} \% \\
(\mathbf{d . w})\end{array}$ & $\begin{array}{c}\mathbf{P \%} \\
(\mathbf{d . w} .)\end{array}$ & $\begin{array}{c}\text { K \% } \\
\text { (d.w.) }\end{array}$ & $\begin{array}{c}\text { Mg \% } \\
\text { (d.w.) }\end{array}$ \\
\hline Control & $4.609 \mathrm{I}$ & $1.52 \mathrm{H}$ & $0.20 \mathrm{G}$ & $0.52 \mathrm{H}$ & $1.44 \mathrm{H}$ \\
\hline Kristalon 1 g/l & $6.667 \mathrm{D}$ & $2.10 \mathrm{D}$ & $0.32 \mathrm{CD}$ & $0.62 \mathrm{D}$ & $1.80 \mathrm{D}$ \\
\hline Kristalon 2 g/l & $7.781 \mathrm{~B}$ & $2.81 \mathrm{~B}$ & $0.34 \mathrm{~B}$ & $0.65 \mathrm{~B}$ & $2.10 \mathrm{~B}$ \\
\hline Kristalon 3 g/l & $8.151 \mathrm{~A}$ & $2.95 \mathrm{~A}$ & $0.37 \mathrm{~A}$ & $0.67 \mathrm{~A}$ & $2.30 \mathrm{~A}$ \\
\hline Kristalon 4 g/l & $6.622 \mathrm{E}$ & $1.97 \mathrm{E}$ & $0.31 \mathrm{D}$ & $0.61 \mathrm{DE}$ & $1.73 \mathrm{E}$ \\
\hline Active Grow 1 ml/l & $5.367 \mathrm{G}$ & $1.81 \mathrm{~F}$ & $0.27 \mathrm{~F}$ & $0.58 \mathrm{~F}$ & $1.70 \mathrm{~F}$ \\
\hline Active Grow 2 ml/l & $7.358 \mathrm{C}$ & $2.52 \mathrm{C}$ & $0.30 \mathrm{BC}$ & $0.64 \mathrm{C}$ & $2.05 \mathrm{C}$ \\
\hline Active Grow 3 ml/l & $5.833 \mathrm{~F}$ & $1.81 \mathrm{~F}$ & $0.29 \mathrm{E}$ & $0.60 \mathrm{E}$ & $1.71 \mathrm{~F}$ \\
\hline Active Grow 4 ml/l & $5.254 \mathrm{H}$ & $1.76 \mathrm{G}$ & $0.26 \mathrm{~F}$ & $0.57 \mathrm{G}$ & $1.65 \mathrm{G}$ \\
\hline
\end{tabular}

* Means within a column having the same letters are not significantly different according to Duncan's New Multiple Range $\mathrm{t}$-Test as $5 \%$ level. 


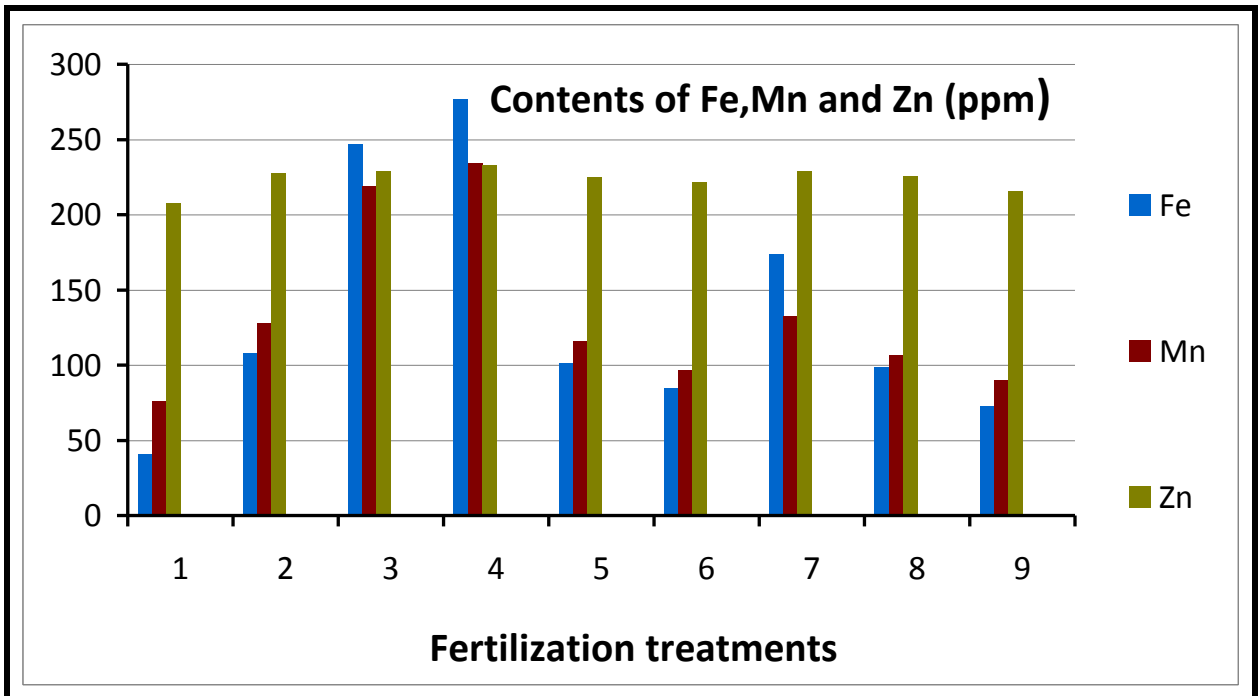

Fig.(3): Contents of $\mathrm{Fe}, \mathrm{Mn}$ and $\mathrm{Zn}$ in response to the fertilization treatments of kristalon and active grow (average of two seasons).

Where: treatment 1:control; treat.2: kristalon 1g/l, treat.3: kristalon $2 \mathrm{~g} / \mathrm{l}$,treat.4: kristalon $3 \mathrm{~g} / \mathrm{l}$,treat.5: kristalon 4 $\mathrm{g} / \mathrm{l}$, treat.6: active grow $1 \mathrm{ml} / \mathrm{l}$,treat.7: active grow $2 \mathrm{ml} / \mathrm{l}$; treat. 8 : active grow $3 \mathrm{ml} / \mathrm{l}$ and treat.9: active grow $4 \mathrm{ml} / \mathrm{l}$.

Furthermore, Shahin and Dorgham (2018) postulated that spraying the foliage of Browallia speciosa and Thevetia peruviana with potassein$\mathrm{N}$ at $2 \mathrm{ml} / \mathrm{l}$ level raised chlorophyll a, b, carotenoids, $\mathrm{N}, \mathrm{P}$ and $\mathrm{K}$ concentrations in the leaves of both plants.

The previous gains are in parallel with those detected by El-Fouly et al. (2014) on Cordyline terminalis, Arab et al. (2015) on Calendula officinalis, Naseem et al. (2015) on Murraya exotica and Arafa et al. (2019) on Ixora coccinea.

According to the abovementioned results, it can be proposed to fertilize the Mescal-bean (Sophora) seedlings with Kristalon (20 N: 20 P: $20 \mathrm{~K}+$ microelements) at $3 \mathrm{~g} / \mathrm{l}$ as foliar spray, once every two weeks, to accelerate their growth with high quality during the rearing period in the nursery.

\section{REFERENCES}

Abdou M. A. and Badran F. S. (2018). Effect of NPK fertilization and micrunutrients on Delonix regia seedlings grown in sandy soil. Hort. Sci. J. Flowers \& Ornam. Plants, 5 (2): 151-159.

Abou-Dahab A. M., Saadawy F. M., Helme, Samia S. and Abul-Magd Salma, S. (2015). Effect of some chemical and biofertilizers treatments on growth of Kochia scoparia L. plant. J. Hort. Sci. \& Ornam. Plants, 7 (3): 124-130.
Ali A. F., Abdou A. H. and Rashed O. (2017). Effect of cutting heights and mineral NPK and/or biofertilization treatments on Moringa oleifera L. plants. Hort. Sci. J. Flowers and Ornam. Plants, 4 (2):209223.

Arab A., Zamani G.R., Sayyari M. H. and Asili J. (2015). Effects of chemical and biofertilizers on morpho-physialogical traits of Calendula officinalis L. Euro. J. Medi. Plants, 8 (1): 60-68.

Arafa Azza M. S., Darwish Mona A., El-Sayed Boshra A. and Ahmed Ghada D. (2019). The effect of NPK levels combined with phosphorein or foliar nutrition (humic acid or potassein) on flowering of Ixora coccinea L. plants. Plant Archives, 19 (2): 2315-2320.

Badran F. S., Abdou M. A., El-Sayed A. A., ElSayed B. A. and Gohar A. A. (2017). Effect of growing media and fertilization treatments on growth and flowering of Gardenia jasminoides plants. Sci. J. Flowers and Ornam. Plants, 4 (1): 131141.

Blacke C. A. (1965). Methods of Soil Analysis Part 1. Physical and Mineralogical Properties Including a Statistics of Measurement and Sampling. Amr. Soc. Agron. Inc., Pub., Wisconsin., U.S.A.

Dubois M., Smith F., Illes K. A., Hamilton J. K. and Rebers P. A. (1956). Colorimetric 
mehod for determination of sugars and related substances. Ann. Chem., 28 (3): 350-356.

El-Azzony E. A., El-Mogy E. E. and El-Shaip N. S. (2018). Response of Jatropha curcas L. shrubs to NPK fertilizer, bio and organic fertilizers under sandy soil conditions. Sci. J. Flowers and Ornam. Plants, 5 (3): 245-259.

El-Fouly Amal S. (2015). Effect of some fertilization treatments on growth and chemical composition of Ochna serrulata (Hochst.) Walp shrubs. Sci. J. Flowers \& Ornam. Plants, 2 (2). 175-182.

El-Fouly Amal S., El-Sayed B. A. and Shahin S. M. (2014). Effect of foliar spraying with humic acid and chelated microelements on growth and quality of Goodluck (Cordyline terminalis L. Kunth.) plant. Minufiya J. Agric. Res., 39 (1): 205- 213.

El-Mokadem Hoda E. and Sorour Mona (2014). Effect of bio and chemical fertilizers on growth and flowering of Petunia hybrida plants. Amer. J. Plant Physio., 9 (2): 6877.

Fayaz K., Singh D., Singh V. K., Bashir D. and Kuller L. R. (2016). Effect of NPK on plant growth, flower quality and yield of gerbera (Gerbera jamesonii). Res. Environ., Life Sci., 9 (11): 1361-1363.

Huxley A., Griffiths M. and Levy M. (1992). The New Royal Hort. Society Dictionary of Gardening. The Stockton Press, 257 Park Avenue South, New York, N. Y. 10010, USA, vol. 2, 747 p.

Ibrahim Hanan E., Abdel-Moniem Azza M. and El-Fouly Amal S. (2014). Effect of some fertilization treatments on growth, flowering and chemical composition of wild garlic (Tulbaghia violacea L.) plant. J. Biol. Chem. \& Environ. Sci., 9 (4):165180.

Jackson M. H. (1973). Soil Chemical Analysis. Prentice-Hall of India Private Limited M-97, New Delhi, India, 498p.
Luatanab F. S. and Olsen S. R. (1965). Test of an ascorbic acid method for determining phosphorus in water and $\mathrm{NaHCO}_{3}$ extracts from soil. Soil Sci. Soc. Amer. Proc., 29: 677-678.

Mead R. , Curnow R. N. and Harted A. M. (1993). Statistical Methods in Agriculture and Experimental Biology. $2^{\text {nd }}$ Ed., Chapman \& Hall Ltd., London, 335 p.

Naseem M. K., Khan M. A., Younis A. and Ahmed R. (2015). Exploiting the nutritional requirement for growth, flower production and phytochemical profile of Murraya exotica. Pak. J. Agic. Sci., 52 (2): 377-384.

Said Reem M. and Shahin S.M. (2019). The role of amino acids, potassium and selenium in improving growth of Eucalyptus citriodora Hook plants and their tolerance to frost. J. Plant Product., Mansoura Univ., 10 (8): 715-719.

SAS Institute (2009). SAS/STAT User`s Guides Statistics. Vers. 6.04, $4^{\text {th }}$ Ed., SAS. Institute Inc. Cary, N.C., USA.

Shahin S. M. and Dorgham Abla H. (2018). Response of Browallia speciosa Hook and Thevetia peruviana (Pers.) K. Schum. plants to some growing media and fertilization treatments. Alex J. Agric. Sci., 63 (4): 263-273.

Shahin S. M., El-Tayeb H. F. and El-Sayed Boshra A. (2012). Effect of some media and fertilization treatments on growth and quality of some foliage pot-plants. J. Biol. Chem. \& Environ. Sci., 7 (1): 93-112.

Steel R. G. D. and Torrie J. H. (1980). Principles and Procedures of Statistics. McGrow Hill Book Co., Inc., New York, USA, pp 377400.

Sumanta N., Haque C. I., Nishika J. and Suprakash R. (2014).Spectrophotometric analysis of chlorophyllous and carotenoids from commonly grown Fern sp. by using various extracting solvents. R. J. Chem. Sci., 4(9): $63-69$. 


$$
\text { 2- تأثير بعض معاملات التسميد على النمو وإنبات وتسميب نبات السوفيماوي لثتلات السوفورا }
$$

(Sophora secundiflora)

\section{أحمد وهبة سيد}

قسم بحوث نباتات الزينة وتنسيق الحدائق، معهُ بحوث البساتين، مركز البحوث الزراعية، الجبيزة، مصر.

\section{ملخص المص}

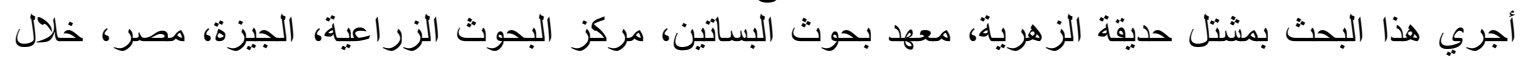

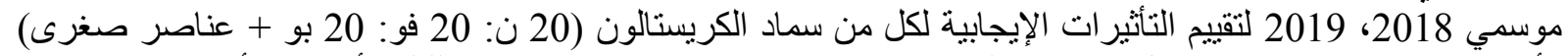

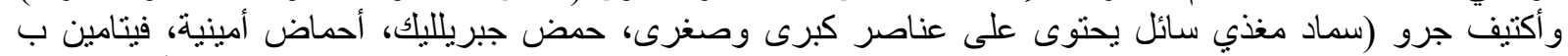

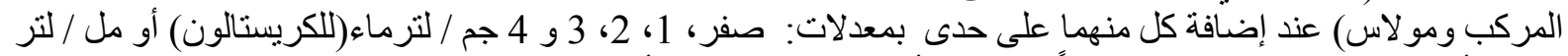

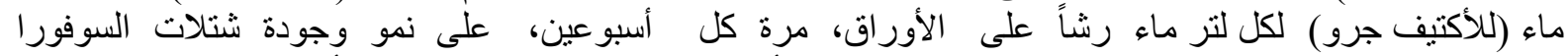
(Sophora secundiflora)

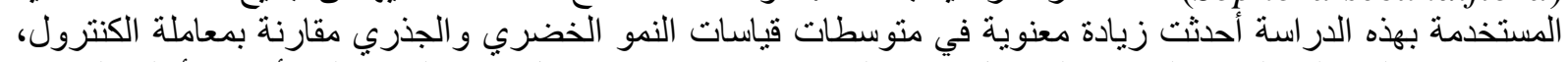

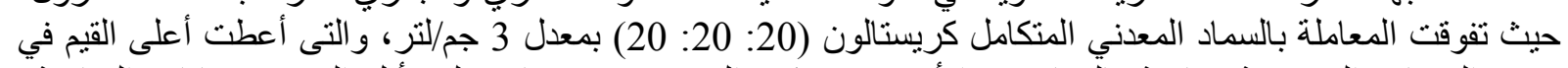

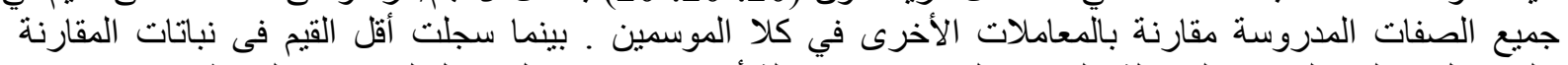

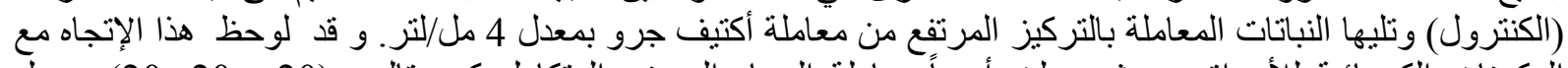

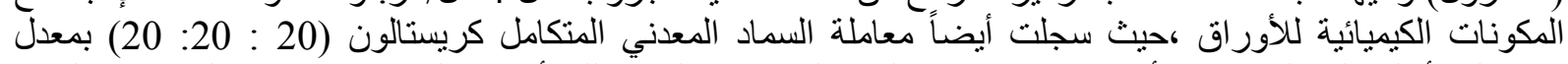

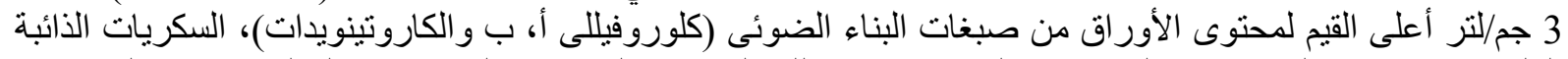

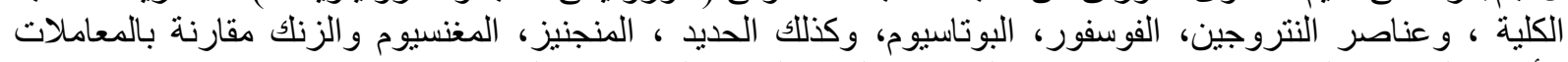

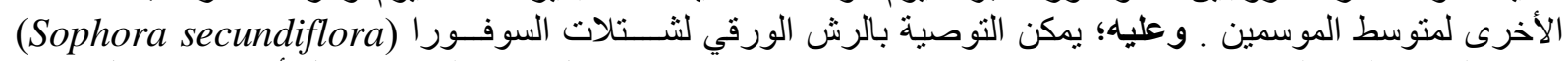

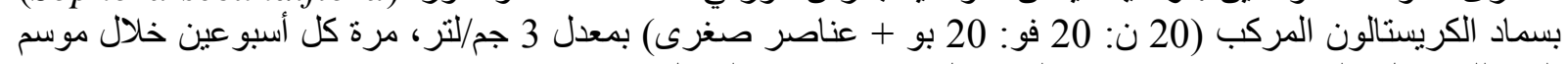

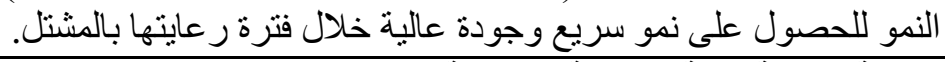

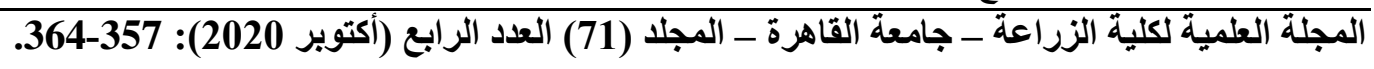

